\title{
OPEN Author Correction: Pectin as an Extraordinary Natural Kinetic Hydrate Inhibitor
}

\section{Shurui Xu, Shuanshi Fan, Songtian Fang, Xuemei Lang, Yanhong Wang \& Jun Chen}

Correction to: Scientific Reports https://doi.org/10.1038/srep23220, published online 21 March 2016

This Article contains an error in Figure 2. During the final preparation of the figures prior to publication, the wrong version of Figure 2 containing an incorrect graph legend was used. The correct Figure 2 appears below as Figure 1.

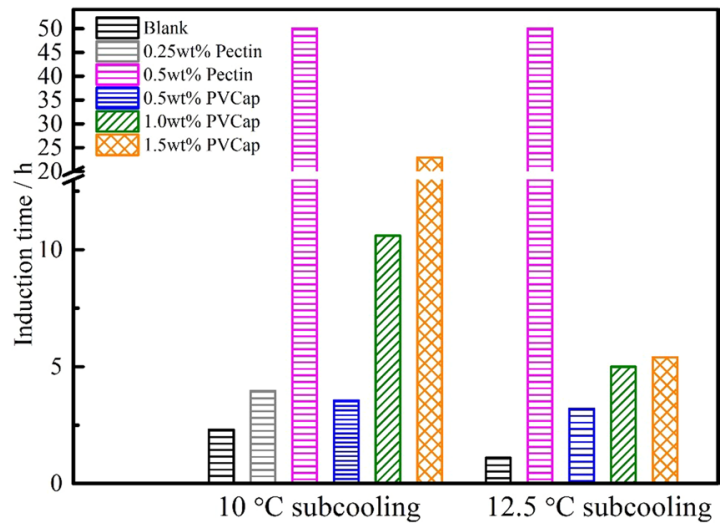

Figure 1.

(c) Open Access This article is licensed under a Creative Commons Attribution 4.0 International Ly License, which permits use, sharing, adaptation, distribution and reproduction in any medium or format, as long as you give appropriate credit to the original author(s) and the source, provide a link to the Creative Commons license, and indicate if changes were made. The images or other third party material in this article are included in the article's Creative Commons license, unless indicated otherwise in a credit line to the material. If material is not included in the article's Creative Commons license and your intended use is not permitted by statutory regulation or exceeds the permitted use, you will need to obtain permission directly from the copyright holder. To view a copy of this license, visit http://creativecommons.org/licenses/by/4.0/.

(C) The Author(s) 2020 